The Practice of Justice

$=$ 



\section{The Practice of}

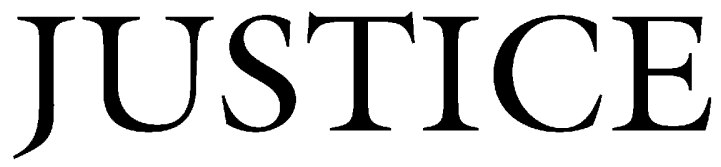

A Theory of Lawyers' Ethics

\section{William H. Simon}

Harvard University Press

Cambridge, Massachusetts

London, England 
Copyright @ 1998 by the President and Fellows of Harvard College All rights reserved

Printed in the United States of America

Second printing, 2000

First Harvard University Press paperback edition, 2000

Library of Congress Cataloging-in-Publication Data

Simon, William $\mathrm{H}$.

The practice of justice / William H. Simon.

p. $\mathrm{cm}$.

ISBN 0-674-69711-1 (cloth)

ISBN 0-674-00275-X (pbk.)

1. Practice of law-United States-Philosophy. 2. Legal ethicsUnited States-Philosophy. I. Title.

KF300.S55 1998

$97-40929$

$174^{\prime} .3^{\prime} 0973-\mathrm{dc} 21$

This book has been digitally reprinted. The content remains identical to that of previous printings. 
For Gary Bellow 
